\title{
Dai tracciati alle strutture stereotomiche: analisi di alcuni sistemi voltati della cattedrale di Murcia (Spagna)
}

Alessio Bortot

Abstract

All'interno della Cattedrale di Murcia si trova un importante repertorio di sistemi voltati, di grande raffinatezza strutturale e decorativa, realizzati con tecniche stereotomiche. Tra le figure coinvolte in questa vicenda troviamo il pittore e architetto Jacopo Torni (1476-1526) e il trattatista Alonso de Vandelvira (1544-1626). Una campagna di rilievo con tecniche fotogrammetriche ha permesso di ottenere i cloni digitali delle principali volte a copertura delle numerose cappelle presenti all'interno della cattedrale. II contributo si concentra sull'analisi dei tracciati presenti nel trattato di Vandelvira di due casi studio piuttosto desueti nel repertorio legato a tale tecnica costruttiva: la volta a copertura della Capilla de Junteron e quella che interessa lo spazio dell'anti sagrestia. I disegni del trattatista spagnolo (in parte confrontati con soluzioni analoghe proposte da Philibert de L'Orme) verranno impiegati, assieme ai cloni digitali ottenuti attraverso il rilievo delle due coperture, per lo studio geometrico e la relativa modellazione 3D degli apparati stereotomici dei due manufatti. Quanto dedotto dai casi studio propone alcune riflessioni sul rapporto tra la pratica del trait e l'effettiva realizzazione di strutture stereotomiche.

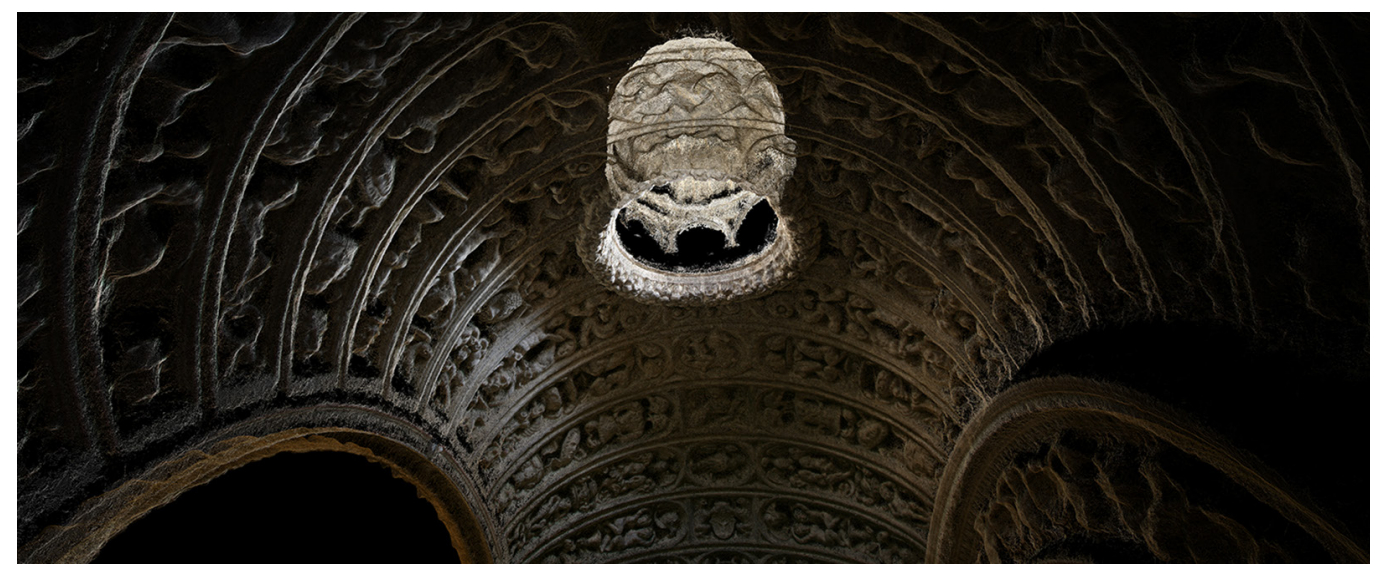


La Cattedrale di Murcia (Spagna) è il frutto di un'intensa attività edificatoria che si protrasse dal I49 I, con l'inizio della costruzione della Capilla de los Vélez, al I 570 [Gutiérrez-Cortines Corral 1987]. Tra i principali promotori di questa vicenda troviamo il protonotario apostolico don Gil Rodríguez de Junterón ( 1480?-1552), prelato che visse e lavorò a Roma per alcuni anni all'inizio del Cinquecento. Rientrato in patria Junterón decise di far edificare una cappella funeraria che prese il suo nome e che a oggi risulta tra le più mirabili dal punto di vista della complessità formale e degli apparati decorativi dell'intero edificio. Più in generale il complesso religioso murciano rappresenta una testimonianza esemplare della scuola stereotomica spagnola che vede tra i suoi più importanti trattatisti Alonso de Vandelvira (I544- |626). La detta cappella funeraria, così come quelle realizzate nella cattedrale nel secondo decennio del I500, risentono di un gusto stilistico riconducibile al Rinascimento italiano, in particolare riferibile alla produzione architettonica di Filippo Brunelleschi ( 1377 |446), di Bramante (|444-I5I4) e di Michelangelo (1475- I564). Quanto affermato non deve stupire se consideriamo che molti di questi ambienti vennero realizzati in quegli anni dal pittore e architetto Jacopo Torni (I476-1526) detto Jacopo Fiorentino [I]. Oltre alla

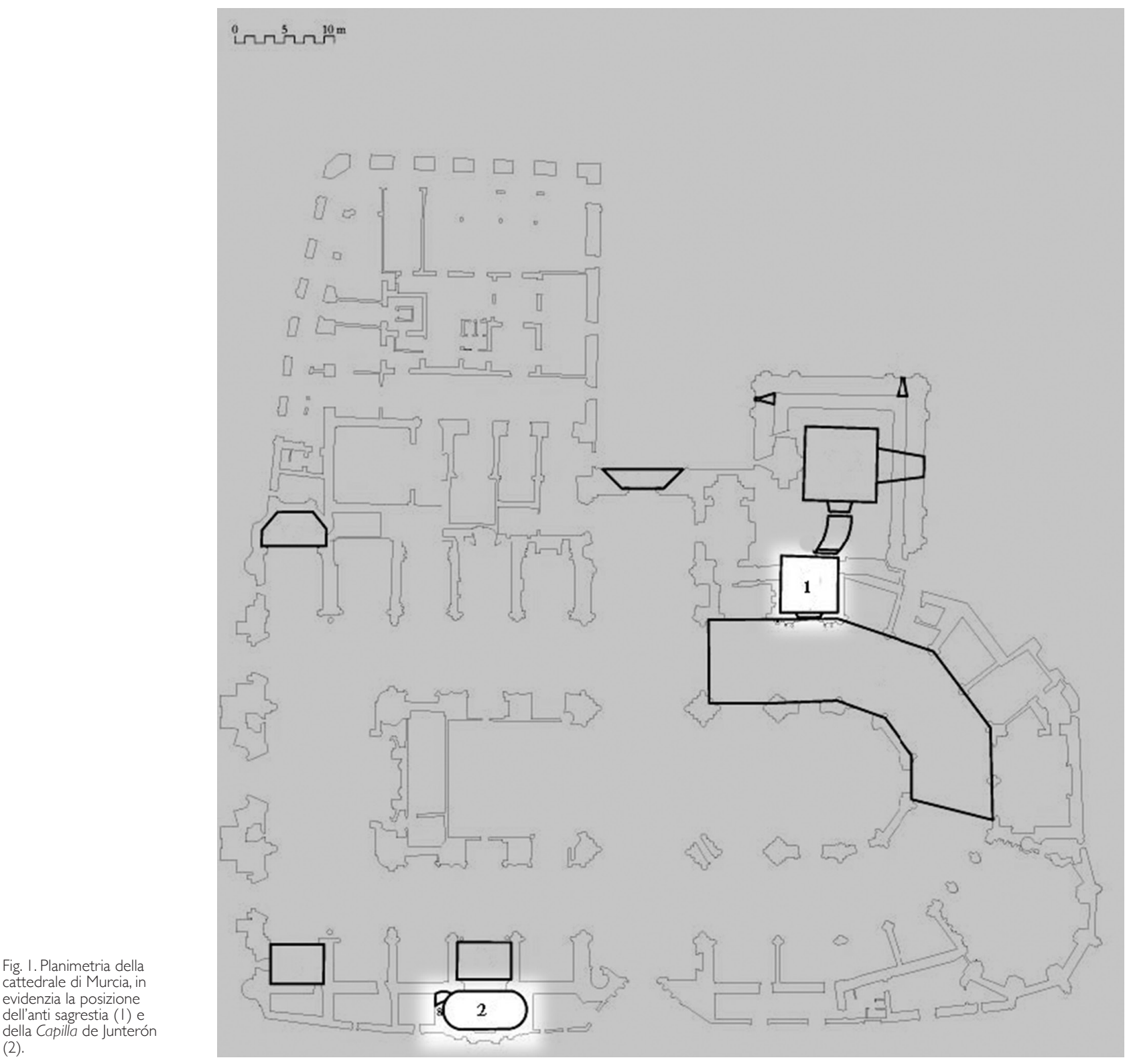


detta cappella funeraria, il Torni fu autore del primo ordine della torre campanaria, della sagrestia, dell'anti-sagrestia e del passaggio voltato che connette i due ambienti. II presente contributo descriverà alcune ipotesi sulle possibili strategie geometriche impiegate per la suddivisione in conci della volta che caratterizza la Capilla de Junterón e quella che interessa lo spazio dell'anti-sagrestia (fig. I).

La Capilla de Junterón (fig. 2) è caratterizzata da una pianta rettangolare coronata da due semicirconferenze sui lati corti, planimetria definita da Vandelvira ovalada o ovale imperfetto. Sappiamo che nella prassi compositiva dell'epoca una tale configurazione planimetrica prevedeva di norma una volta a botte a copertura della porzione rettangolare e due quarti

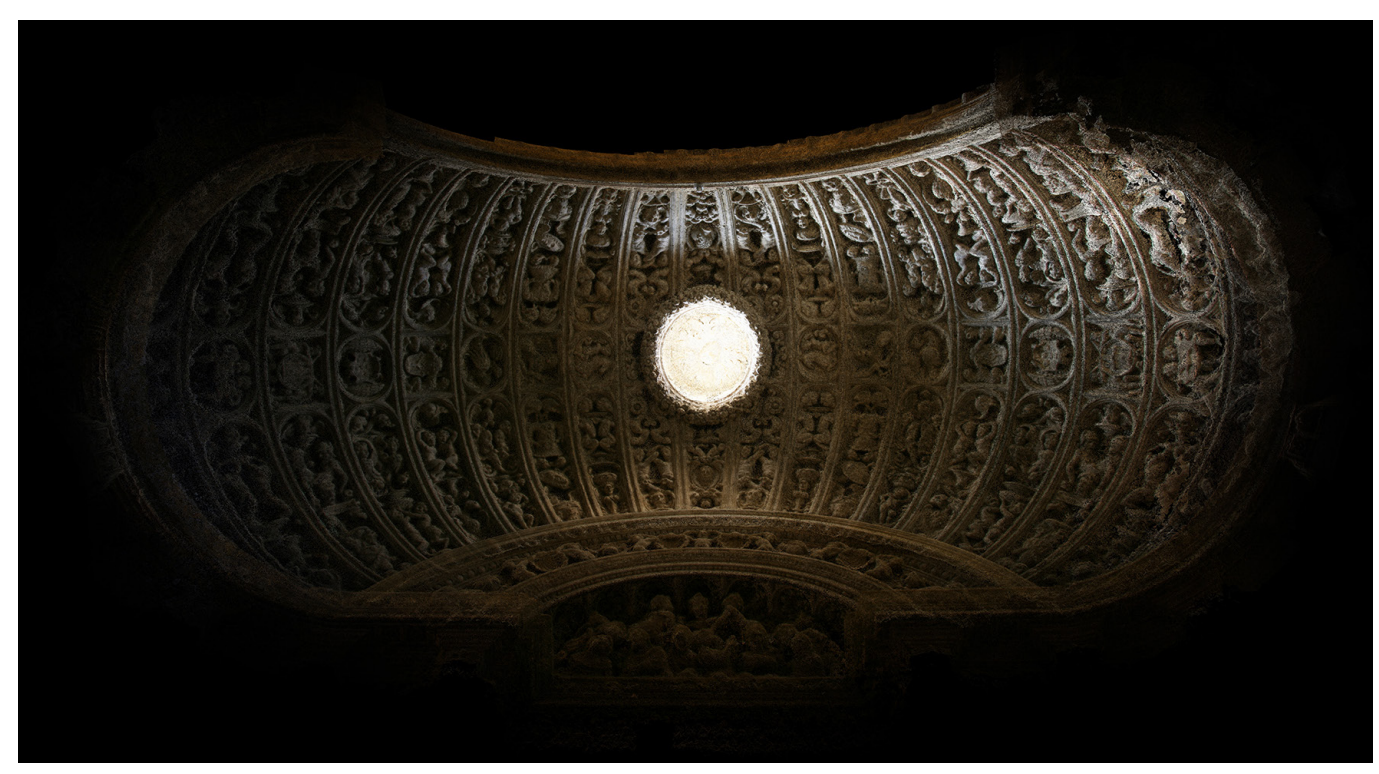

di sfera nelle due testate delle restanti parti curvilinee. La soluzione del Torni risulta invece piuttosto desueta, si tratta infatti di una volta anulare identificabile con un quarto di toro, risultato della rivoluzione di $180^{\circ}$ di uno dei semi-equatori attorno all'asse trasversale appartenente al piano d'imposta (fig. 3a). L'ambiente viene illuminato da alcune piccole finestrature presenti sulle superfici verticali ma anche da una lanterna cilindrica posta nella parte centrale alla sommità della volta. Come sappiamo più usuale è l'impiego di un semi-toro a copertura di porticati circolari già in epoca romana, in quel caso però l'asse della superficie è orientato verticalmente come capita ad esempio nel Mausoleo di Santa Costanza a Roma (340 circa).Vandelvira nel suo trattato [Vandelvira I 585 ca.; Barbé-Coquelin de Lisle 1977] suggerisce di suddividere la superficie impiegando due serie di coni coassiali, la prima serie con vertice comune e asse orizzontale coincidente con quello trasversale della pianta, la seconda con asse che segue la medesima direzione ma con vertici variabili [López 2005, pp. 123-I36] [2]. II trattatista spagnolo afferma che il metodo necessario all'ottenimento dell'apparato stereotomico è il medesimo impiegato per la capilla redonda en vuelta redonda, ovvero per una volta semisferica. Seppur inquadrando entrambe le superfici come prodotto della rivoluzione di una circonferenza attorno a un asse, la soluzione poc'anzi esposta crea un certo stupore, o meglio necessita di maggiore chiarezza. II problema è ricorrente nella trattatistica del periodo e si riferisce nello specifico all'impiego di superfici rigate per approssimare le facce di intradosso di ciascun concio, poiché essendo porzioni di sfera risultano non sviluppabili e quindi difficilmente riconducibili ai così detti paneaux; i coni in esame avranno quindi un asse comune ma vertice variabile in funzione dell'inclinazione delle generatrici che avvicinandosi all'equatore della superficie tendono sempre più al parallelismo rispetto all'asse di rivoluzione, fino al caso limite in prossimità dell'equatore dove il cono si presenta a vertice improprio e quindi approssima le facce di intradosso a porzioni 
Fig. 3. Ricostruzione geometrica dalla tavola del trattato di Alonso de Vandelvira (a), studio della suddivisione dell'apparato stereotomico in meridiani e paralleli (b) e dell'approssimazione delle facce di intradosso dei conci a porzioni di coni

(c), (elaborazione digitale A. Bortot). di cilindro (fig. 3c). L'impiego di superfici rigate sviluppabili per tali operazioni divenne una prassi consolidata, una sorta di scorciatoia geometrica capace di garantire un margine di approssimazione accettabile, come dimostrato da altri autori [Rabasa-Díaz 2000, pp. I74, 175]. II problema continuerà ad attrarre l'attenzione degli studiosi, ma sarà necessario attendere i primi decenni del 1700, grazie all'opera di Jean-Baptiste de La Rue (1697-1743), per soluzioni geometriche più raffinate basate di fatto su un metodo che oggi definiremo "di ribaltamento" [Bortot, López 2020, pp. 2 I -34]. Le tavole del trattato di Vandelvira che accompagnano la descrizione della volta della cappella Junteron sono due, entrambe mostrano la superficie attraverso una coppia di proiezioni ortogonali, nello specifico una vista superiore e una frontale, però mentre la prima tavola si concentra sui tracciati delle fughe dei conci tra loro coordinati, la seconda propone un apparato decorativo a costoloni che si integra alla struttura (fig. 4). L'osservazione della volta in loco durante il sopralluogo e la successiva ana-

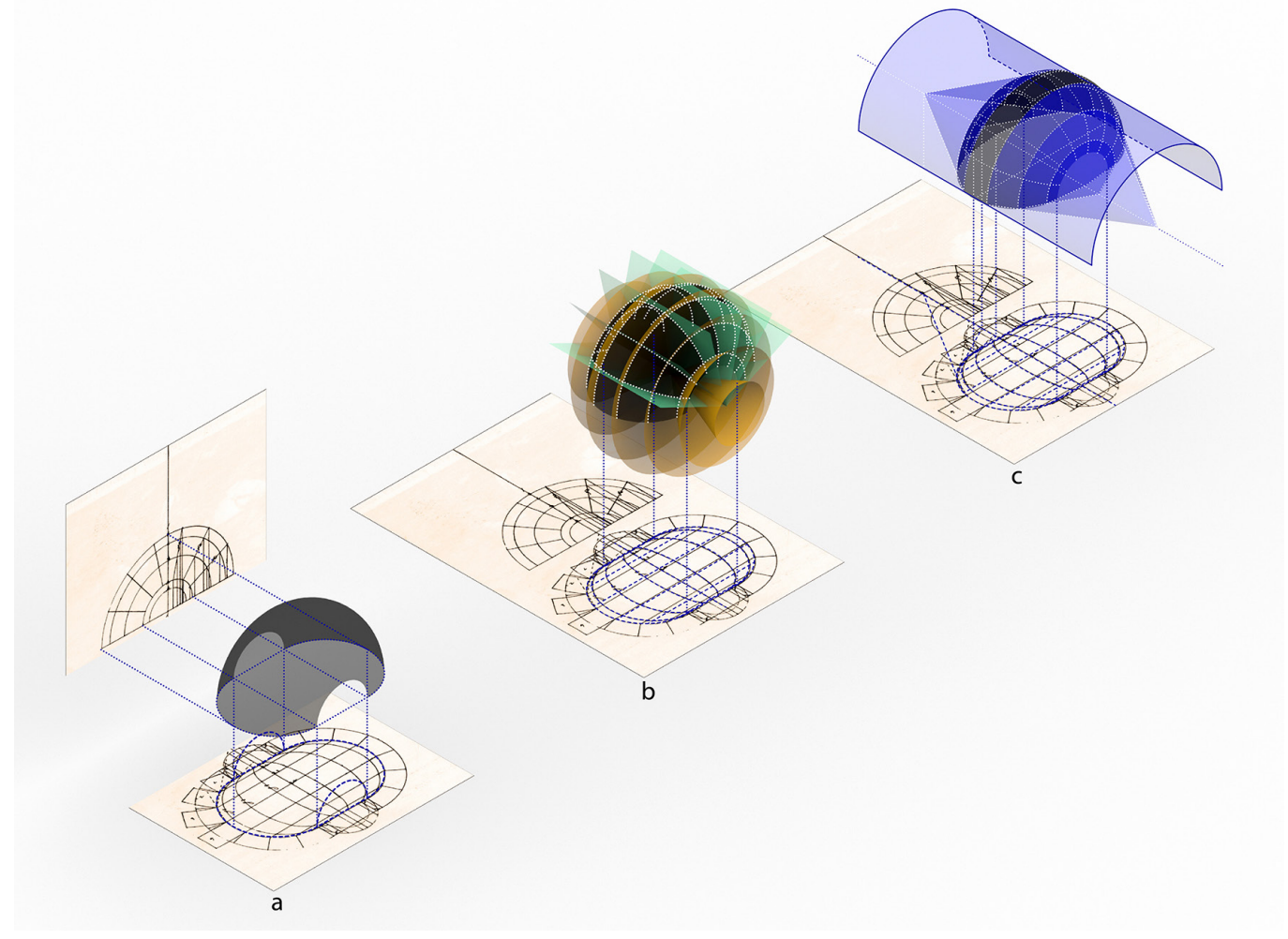

lisi dei tracciati del trattatista spagnolo hanno permesso di ipotizzare gli enti geometrici che una volta intersecati con la porzione di volta anulare permettono la definizione di meridiani e paralleli: intersecando una serie di coni, questa volta con vertice comune coincidente con il centro dell'ovoide e ad asse orizzontale (coincidente con quello trasversale dell'ovoide), con la porzione di toroide si generano dei paralleli analoghi a quelli definiti graficamente da Vandelvira; invece attraverso l'intersezione con la superficie di un fascio di piani ad asse orizzontale viene garantita la generazione di semi-circonferenze nello spazio che una volta proiettate sul piano geometrale mostrano i meridiani sotto forma di archi di ellissi (fig. 3b). Quest'ultima soluzione è quella che meglio approssima il tracciato di Vandelvira e tra l'altro è quella che, come diremo, risulta applicabile anche alla suddivisione in conci di una volta semisferica, capace quindi di offrire una chiave interpretativa a quanto affermato dal trattatista andaluso in relazione alla presunta analogia stereotomica tra volte sferiche e anulari. Oltre che per la sua originalità configurativa la volta descritta stupisce per l'iper-decorativismo che la caratterizza, immagini pagane, spesse volte perturbanti, si contorcono ed emergono dai singoli blocchi lapidei, ma sembrano alludere più che a una dimensione funerea a un suo 
Fig. 4. La Bóveda de Murcia (a sinistra), dal manoscritto di A. de Vandelvira; la Bóved de Murcia por cruceros dal manoscritto di A de Vandelvira (a destra). catartico superamento, a un'ascesi verso l'eterno [Vilella 1998, p. 93]. Gli altorilievi scultorei infine testimoniano una tendenza della pratica stereotomica in ambito iberico che demarca una significativa differenza rispetto ai casi coevi presenti in territorio francese, quest'ultimi infatti mostrano il più delle volte una purezza strutturale priva di sovrastrutture decorative. La volta a copertura dell'anti-sagrestia della cattedrale di Murcia (fig. 5), realizzata nei primi decenni del 1600, risulta nuovamente legata al trattato di Alonso de Vandelvira ( 1544 1626) dove viene identificata come capilla redonda en vuela capazo. La volta emisferica si imposta su quattro pennacchi sferici che si appoggiano ad altrettanti archi, a loro volta in

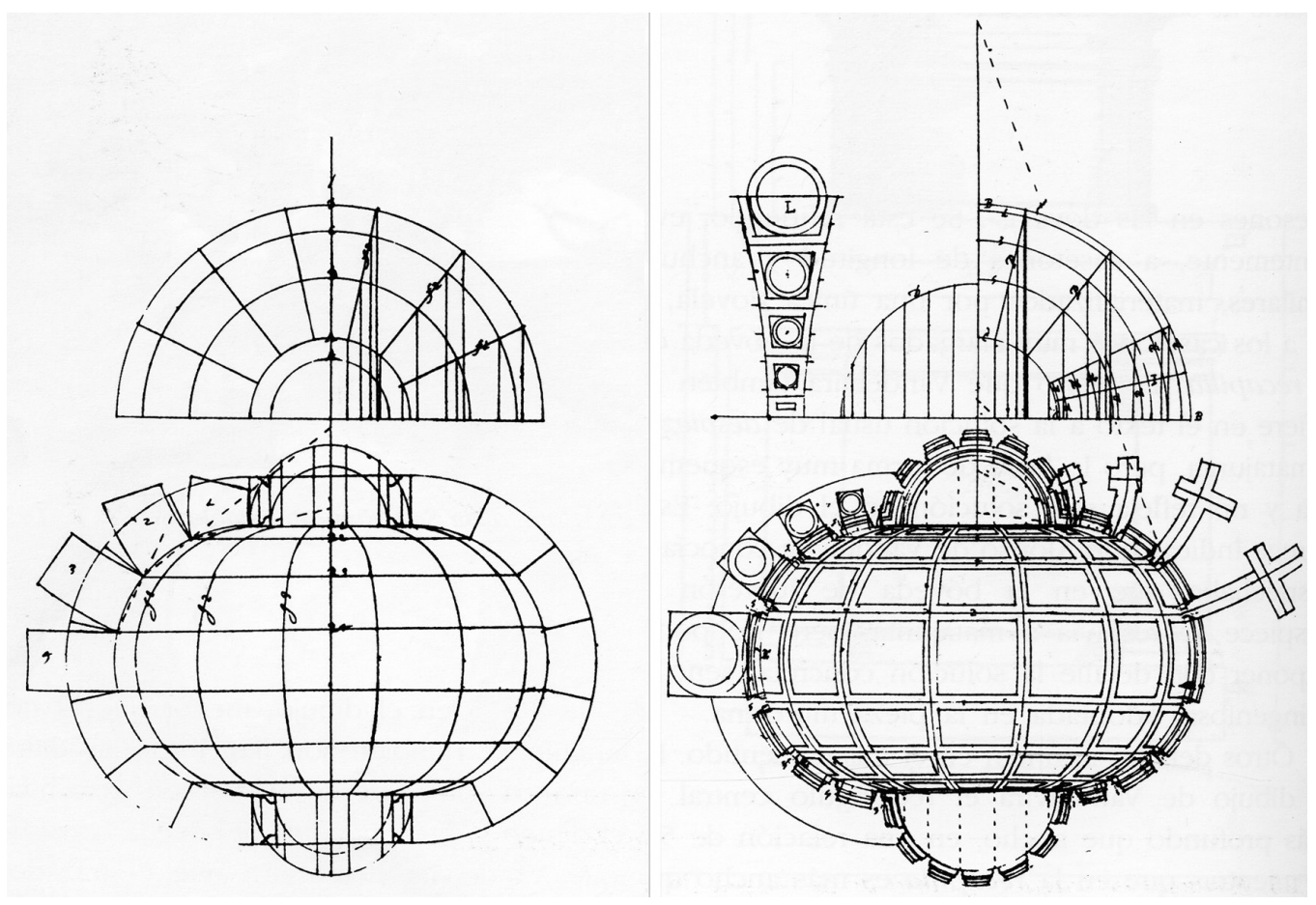

continuità con i muri che delimitano l'ambiente di forma quadrata. Probabilmente a causa del crollo in fase costruttiva del primo livello dall'adiacente torre campanaria, la struttura ha subito significative deformazioni tutt'oggi visibili, sebbene il restauro del 200 l abbia in parte addolcito le difformità tra i conci presenti sulla volta, ma soprattutto tra quelli presenti nel pennacchio posto a nord-est. II sopralluogo ha permesso anche di osservare la superficie di estradosso della cupola grazie a un passaggio di servizio che consente di accedere all'ambiente sovrastante l'anti-sagrestia (fig. 6). Nella superficie estradossata i conci appaiono comunque sbozzati con una certa precisione a seguire l'andamento sferico dell'intradosso come in un'operazione di offset tridimensionale, compare inoltre la presenza di un legante a rafforzare i giunti, probabilmente inserito durante il restauro di cui si è detto.

Si tratta di un esempio piuttosto raro di suddivisione in conci di una calotta sferica secondo un andamento dei blocchi che segue un percorso a elica. Come già osservato da José Calvo-López [López 2005], una raffigurazione del problema appare nel manoscritto di Vandelvira (fig. 7a) e in quello di Philibert de L'Orme (I5 |4- 1570), [De l'Orme I 567] il quale la definisce "en forme d'une coquille de limaçon" (fig. 7b). II confronto con la tavola proposta da Delorme evidenzia fin da subito una certa incongruenza se rapportata alla volta murciana, in essa infatti l'altezza dei filari risulta all'incirca costante, questo comporta che proiettando sul piano orizzontale il tracciato dell'elica, ne risulta una spirale logaritmica (con distanza tra le spire crescente) e non archimedea (a distanza tra le spire costante), se infatti contro-proiettassimo la spirale logaritmica delormiana dal piano d'imposta alla superficie 
Fig. 5. Vista assonometrica del modello mesh texturizzato della

volta dell'anti sagrestia,

(elaborazione digitale A. Bortot).

Fig. 6. La superficie di estradosso della volta dell'anti sagrestia (foto di A. Bortot).

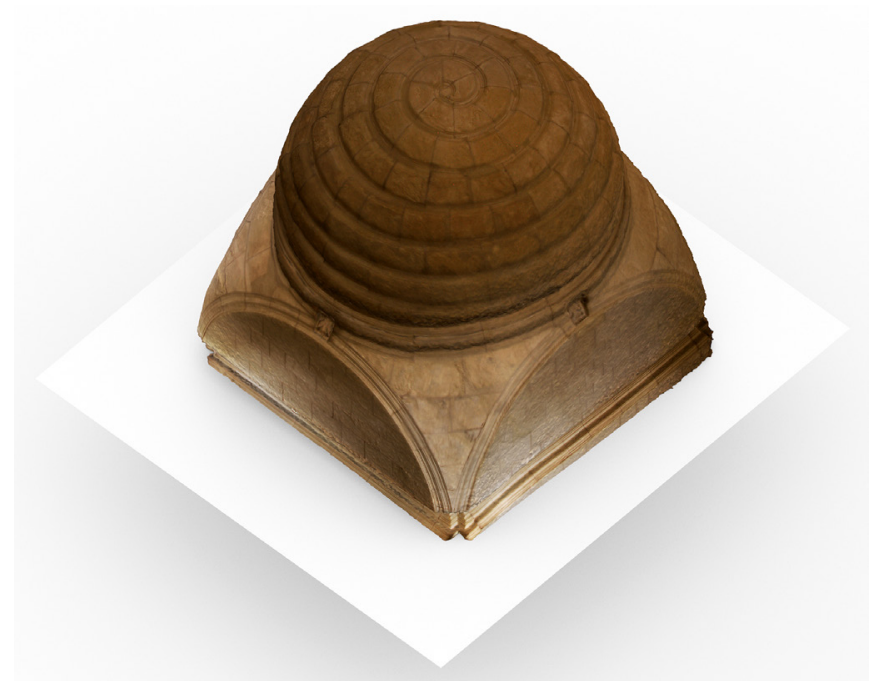

semisfera otterremmo un'elica sferica con altezza variabile delle spire e quindi dei filari. L'incongruenza grafica poc'anzi descritta è riscontrabile anche nel manoscritto [Ruiz I $560 \mathrm{ca}$.] di Hernán Ruiz el Joven ( 15 | 4- 1569), in quello di Jean Chéreau [Chéreau I570], solamente per citare alcuni degli autori che si occuparono di questo problema [3]. L'analisi condotta da José Calvo-López sul tracciato di Alonso de Vandelvira evidenzia invece come la tavola rappresenti la spirale proiezione planimetrica a partire dall'elica spaziale che desidera ottenere. II procedimento consiste nel determinare dapprima l'altezza di ciascun filare di conci, dividendo la sezione verticale in parti uguali. Si suddivide poi la circonferenza della pianta per lo stesso numero di blocchi e conducendo poi da questi punti delle rette verso il centro della volta si ottengono le direzioni dei meridiani della superficie sferica proiettate sul piano

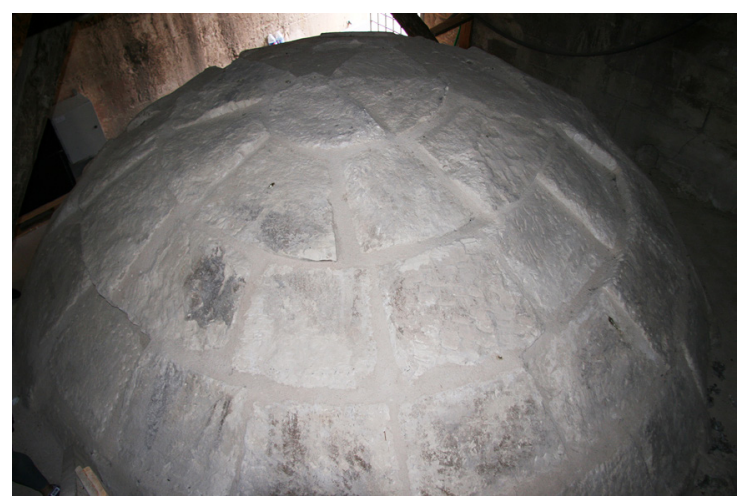

geometrale. In seguito, proiettando i settori individuati in sezione, sarà possibile determinare la distanza costante tra le spire in prima proiezione sulle rette poc'anzi individuate, owvero quelle definenti le porzioni dei meridiani. A questo punto sarà possibile tracciare la prima proiezione della spirale conoscendone il centro e il passo tra le spire coerentemente alla sezione verticale (fig. 8). Alla spirale così definita corrisponderà un'elica spaziale riferibile all'andamento dei giunti di letto dei vari blocchi che risulteranno conseguentemente tutti diversi tra loro. I disegni di De l'Orme e degli altri autori citati, a eccezione diVandelvira, risultano decisamente impraticabili, difficilmente uno scalpellino avrebbe accettato una struttura stereotomica di filari con altezze diverse, se non per una precisa ragione statica difficilmente però identificabile nel caso in esame. 
Fig. 7. La capilla redonda en vuelta capazo, dal manoscritto di Vandelvira (a sinistra); la voute en forme d'une coqulle de limaçon da Le premier tome de 'Architecture di Philibert de L'Orme (a destra).
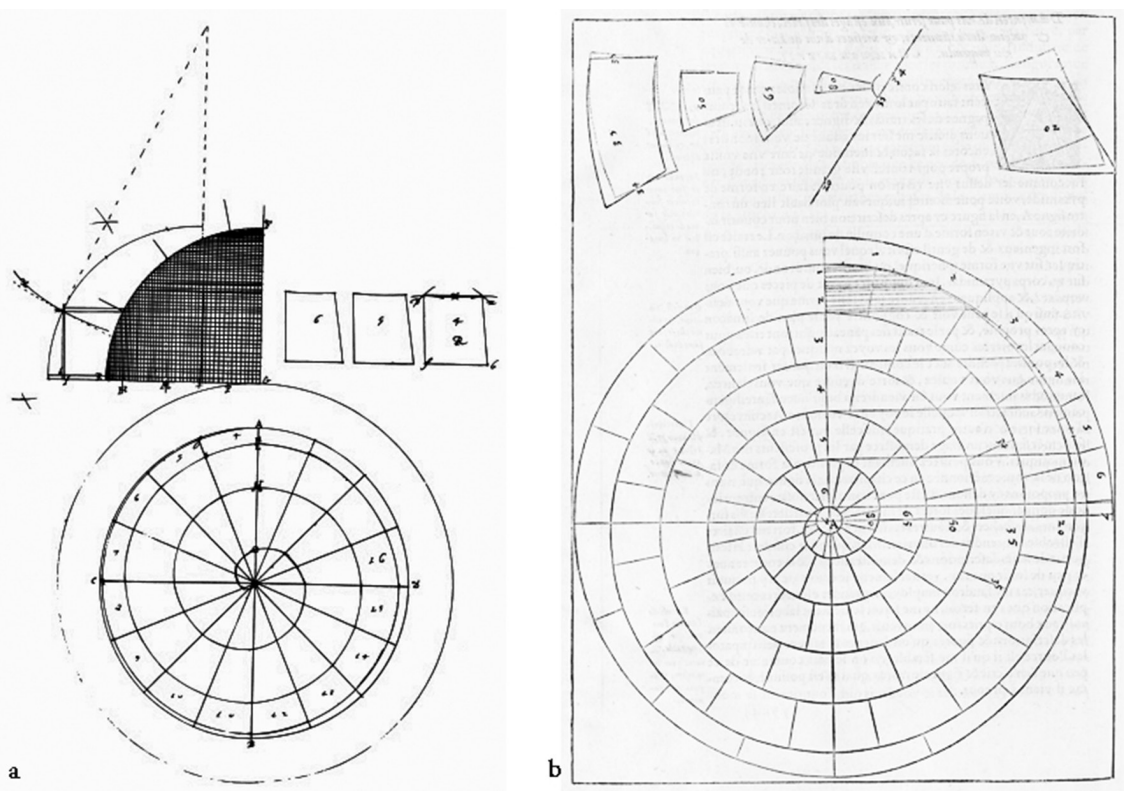

La ricostruzione digitale della volta della cattedrale di Murcia si è basata sull'analisi geometrica del manufatto attraverso un modello mesh mappato della superficie di intradosso ottenuto con tecniche riconducibili alla fotogrammetria multi-stereo [4] (fig. 5). Tenendo in considerazione le deformazioni della volta dovute al crollo in fase costruttiva dell'adiacente torre campanaria, una prima indagine si è concentrata sull'identificazione della curva spaziale che caratterizza i giunti di letto. Inizialmente si è infatti ipotizzato che si potesse trattare di una lossodromia, come sappiamo nota in ambito nautico per il tracciamento delle rotte di navigazione capace di unire due punti qualsiasi sulla superficie terrestre intersecando tutti i meridiani con lo stesso angolo (la curva complementare invece, detta ortodromia, unisce due punti nel loro tragitto minore). II ridisegno dell'elemento in esame direttamente sul clone digitale ha invece permesso di dimostrare che la curva si avvicina, seppur con una certa approssimazione, a un'elica sferica. Le analisi preliminari hanno quindi permesso la ricostruzione di un modello digitale solido e rettificato della volta dell'anti-sagrestia e soprattutto della relativa suddivisione in conci. I 'paralleli' (per semplicità così definiamo i giunti disposti lungo l'elica sferica) sono stati ottenuti intersecando la semisfera con un cono il cui vertice
Fig. 8. Ricostruzione del metodo per stabilire l'altezza costante dei filari nella volta dell'anti sagrestia (elaborazione grafica J. C. Lopez).

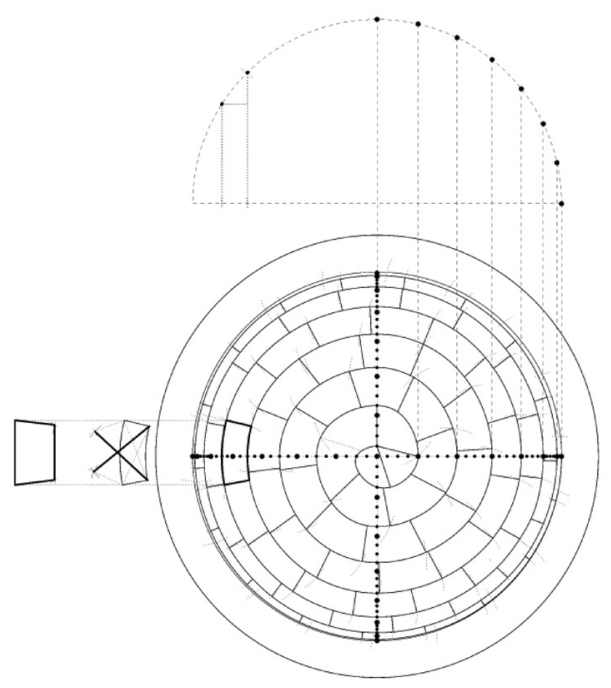


è stato posizionato al centro del quadrato definito dai vertici inferiori dei pennacchi sferici e la cui direttrice è una spirale archimedea con un numero di passi pari a quelli realmente esistenti (fig. 9). I 'meridiani' invece, ovvero i giunti verticali, sono stati ricavati suddividendo la spirale direttrice del cono in un numero di segmenti pari a quelli esistenti e quindi tracciando delle rette congiungenti gli estremi di ciascun segmento con il centro della curva, successivamente sono state proiettate sulla semisfera le porzioni di retta comprese tra una spira e l'altra (fig. I0). Ė stato infine eseguito un offset della superficie d'intradosso per ottenere quella di estradosso, passando da un modello a superfici a uno solido suddiviso in conci (fig. I I) nel quale ciascun blocco ha come facce di testa porzioni di cono e come facce di giunto porzioni di piani. II modello digitale così ottenuto ha in parte rettificato lo stato reale di conservazione del manufatto non considerando le deformazioni dovute al crollo dell'adiacente torre, ma ha invece rispettato il numero e la forma dei singoli conci, per tale ragione non dovrà stupire l'allineamento in alcuni casi tra i giunti verticali di filari consecutivi che, sebbene meno efficienti dal punto di vista strutturale, così risultano posati nella volta dell'anti sagrestia.

Il caso studio appena descritto evidenzia le forti influenze esercitate dalla pratica stereotomica spagnola in ambito francese, tanto che Jean-Marie Pérouse de Montclos sottolinea come "la semplice comparazione degli apparati stereotomici risalenti al XVI secolo porta a riconoscere alla Spagna il ruolo di iniziatrice" [Pérouse de Montclos 1982]. Lo stesso autore però afferma che il caso della capilla redonda en vuela capazo, definita da De l'Orme "en forme d'une coquille de limaçon", altro non sia che una sorta di capriccio, una virtuosistica suddivisione in conci di una volta emisferica troppo complessa per divenire un modello reiterabile. In effetti non sono molti gli esempi analoghi, sebbene in territorio spagnolo congiunti simili si possono osservare talvolta a copertura di scale elicoidali come quella presente nella torre del Palacio de los Guzmanes a León (seconda metà del XVI secolo), o quella della Cattedrale di Plasencia o ancora, quella del Monastero di Santa Catalina a Talavera de la Reina.

In definitiva ci sembra di intravedere nell'opera letteraria di Vandelvira, che ricordiamo pur restando un manoscritto ebbe un'ampia diffusione, un atteggiamento volto alla soluzione pratica dei singoli casi più che alla ricerca di un metodo generale, tendenza quest'ultima che interesserà invece soprattutto gli autori francesi del secolo successivo. II disegno per la volta dell'anti sagrestia murciana, seppur con qualche licenza geometrica, dimostra a nostro

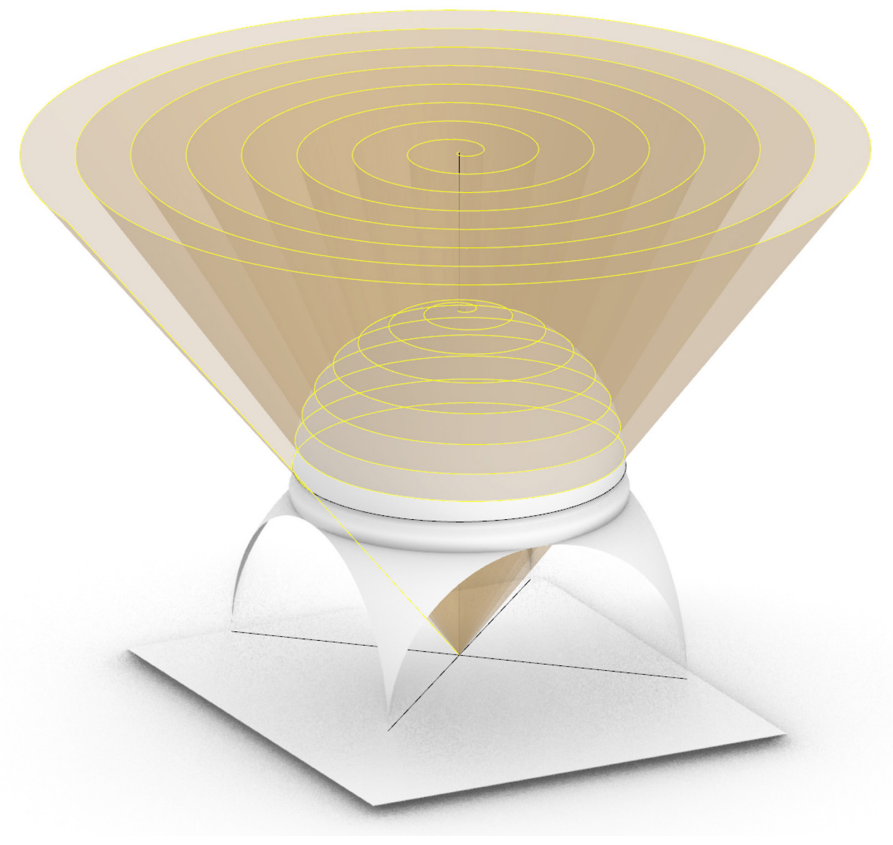


Fig. 10. Ricostruzione

della suddivisione della

volta in giunti verticali,
(elaborazione digitale

A. Bortot)

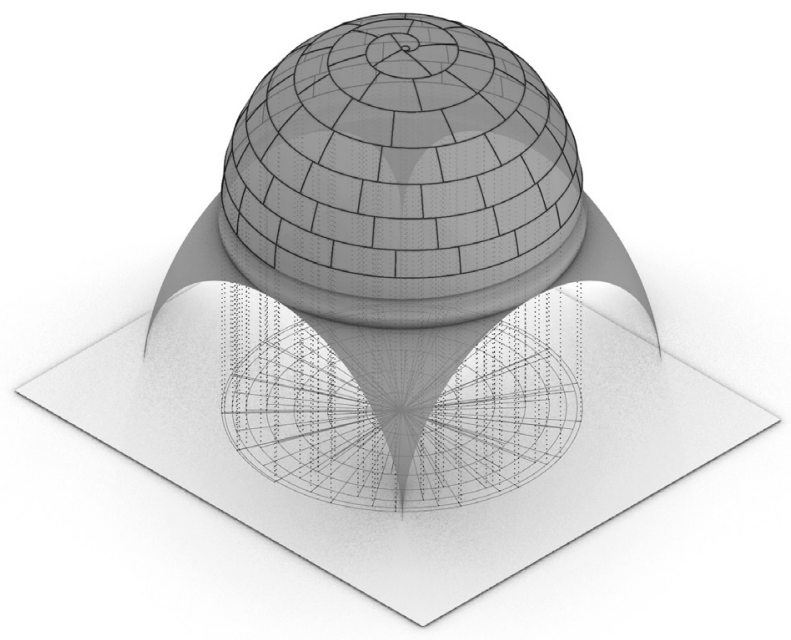

Fig. I I. Modello finale

della volta dell'anti

sacrestia con i con

stereotomici che

la compongono

(elaborazion

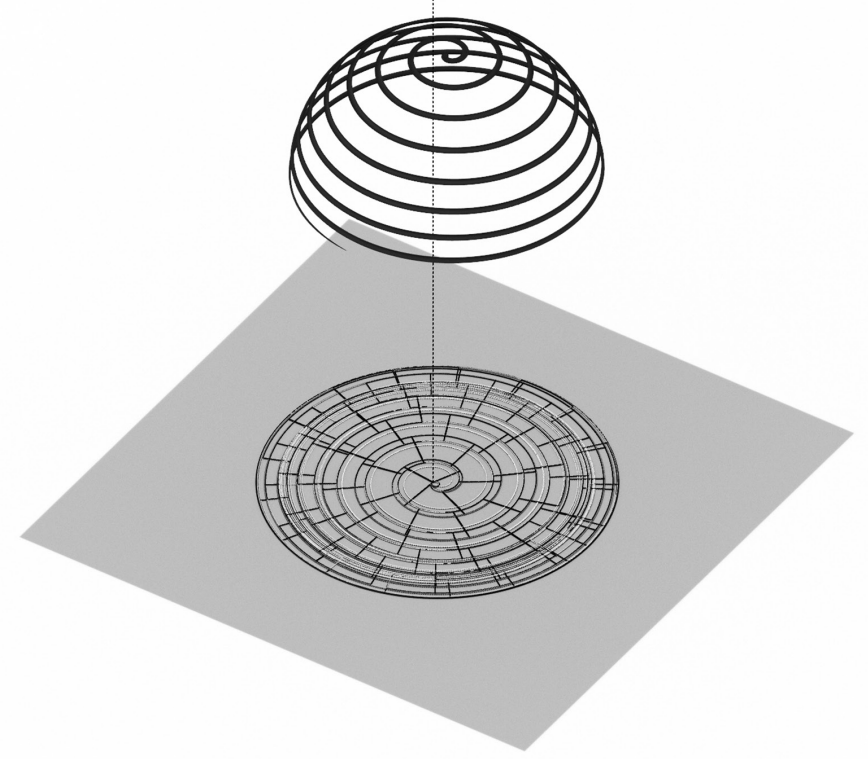


parere una certa coerenza data dalla pratica costruttiva più che dalla speculazione pura, da un'abitudine immaginativo-proiettiva maturata in un'epoca nella quale il disegno di progetto aveva il compito di suggerire la soluzione più che rappresentarne la rigorosa esecuzione.Va da sé che la stereotomia digitale, in questa sede impiegata per l'analisi dei due casi studio, non può invece esimersi dall'affermarsi di un metodo coerente e dettagliato, frutto legittimo della tradizione legata a tale tecnica costruttiva.

\section{Note}

[I] Sulle vicende biografiche di questa figura non si hanno molte informazioni, la principale fonte rimane l'opera di Vasari: Vasari Giorgio ( 1568$)$. Vite de' più eccellenti pittori, scultori, e architettori. Firenze: appresso i Giunti.

[2] Si veda la tesi finale di dottorato di ricerca: E. Trevisan, Intreccio strutturale e vertigine dello sguardo: tettonica, decorazione e attualità della stereotomia nella Cattedrale di Murcia, Scuola di dottorato dell'Università IUAV di Venezia, relatore prof. A. De Rosa, A.A. 2014-2015, tesi di dottorato non pubblicata, pp. I25-143.

[3] Tracciati analoghi appaiono anche in altri manoscritti e trattati successivi alla costruzione della volta di Murcia, si veda ad esempio:Tosca Vicente ( 1794). Tratado de arquitectura civil, montea y cantería y reloxes. Valencia: Hermanos Orga; J. de Partor y Castro, Cuaderno de arquitectura, Biblioteca Nacional, Madrid 1708

[4] II rilievo ha previsto l'impiego della fotocamera Nikon D800e con obbiettivo $24 \mathrm{~mm}$ FI.4 asferico. Gli scatti, ottenuti impostando il valore ISO a 200, sono stati 88 per la Capilla de Junteron e 33 per la volta dell'anti sagrestia. L'elaborazione delle immagini è avvenuta tramite il software Agisoft Metashape.

\section{Riferimenti bibliografici}

Barbé-Coquelin de Lisle Geneviève (a cura di). (1977). Tratado de Arquitectura deAlonso de Vandelvira. Albacenete: Confederacion Espanola de Cajas de Ahorros.

Bortot Alessio, Calvo López José (2020). De la Rue's Traité de la coupe des pierres: a crucial step in the articulation of material stonecutting and abstract stereotomy. In Calvo López José, Bortot Alessio, Piccinin Giulia. Geometria e costruzione. Steretomia e configurazione in architettura. Roma: Aracne.

Calvo López José et al. (2005). Cantería renacentista en la catedral de Murcia. Murcia: Colegio de Arquitectos de Murcia.

Chéreau Jean (1570c.). Livre d'Architecture. s.e.

De L'Orme Philibert ( I567). Le premier tome de l'Architecture. Parigi: Morel.

Gutiérrez-Cortines Corral Cristina (1987). Renacimiento y arquitectura religiosa en la antigua Diócesis de Cartagena, Reyno de Murcia, Gobernación de Orihuela y Sierra del Segura. Murcia: Colegio de Aparejadores y Arquitectos Técnicos.

Pérouse de Montclos Jean-Marie ( 1982). L'architecture à la Française, XVle, XVIle, XVIIle siècles. Parigi: Picard.

Rabasa-Díaz Enrique (2000). Forma y construccion en piedra: De la canteria medieval a la estereotomia del siglo 19. Madrid: Ediciones Akal.

Ruiz el Joven Hernán (1560c.). Libro de Arquitectura. s.e.

Sakarovitch Joel (1998). Épures d'architecture: de la coupe des pierres à la géométrie descriptive, XVI-XIX siècles. Basilea: Birkhäuser.

Vandelvira Alonso (I585 c.). Libro de trazas de cortes de piedras (manoscritto della Biblioteca de la Escuela de Arquitectura de la Universidad Politécnica de Madrid).

Vilella Marzia (1999). Jacopo Torni detto I'Indaco (|476-1526) e la cappella funebre "a La Antigua" di Don Gil Rodríguez de Junterón nella cattedrale di Murcia. In Annali di architettura. Rivista del centro internazionale di Studi di Architettura Andrea Palladio, 10-II, pp. 82-102.

\section{Autore}

Alessio Bortot, Università luav di Venezia, alessio.bortot@iuav.it

Per citare questo capitolo: Bortot Alessio (2020). Dai tracciati alle strutture stereotomiche: analisi di alcuni sistemi voltati della Cattedrale di Murcia (Spagna)/From trait to stereotomic structure: analysis of some vaulted systems in the Murcia Cathedral (Spain). In Arena A., Arena M., Brandolino R.G., Colistra D., Ginex G., Mediati D., Nucifora S., Raffa P. (a cura di). Connettere. Un disegno per annodare e tessere. Atti del $42^{\circ}$ Convegno Internazionale dei Docenti delle Discipline della Rappresentazione/Connecting. Drawing for weaving relationships. Proceedings of the 42th International Conference of Representation Disciplines Teachers. Milano: FrancoAngeli, pp. I 47-I 66. 


\title{
From Trait to Stereotomic Structure: Analysis of some Vaulted Systems in the Murcia Cathedral (Spain)
}

\author{
Alessio Bortot
}

Abstract

In the Murcia Cathedral there is an important repertoire of vaulted systems showing very refined structures and decorations which were built with stereotomic technique. The painter and architect Jacopo Torni (| 476- I 526) and the essayist Alonso de Vandelvira (I544- |626) are some of the personalities who were involved in it. A survey through the use of photogrammetric techniques has allowed to get the digital clones of the main vaults which cover the numerous chapels of the cathedral. This paper focuses on the drawings published in Vandelvira's treatise and analyses in detail two uncommon case studies in the field of this construction technique: the Capilla de Junteron's vault and the one covering the room of the antisagresty. The drawings by Vandelvira (partly compared to similar solutions proposed by Philibert de L'Orme) will be used (along with the digital clones obtained by the survey of the two coverings) to study the geometry and create the 3D modeling of the stereotomic apparatuses of these two ceilings. The analysis of these case studies inspires some considerations on the relationship between the practice of trait and the concrete construction of stereotomic structures.

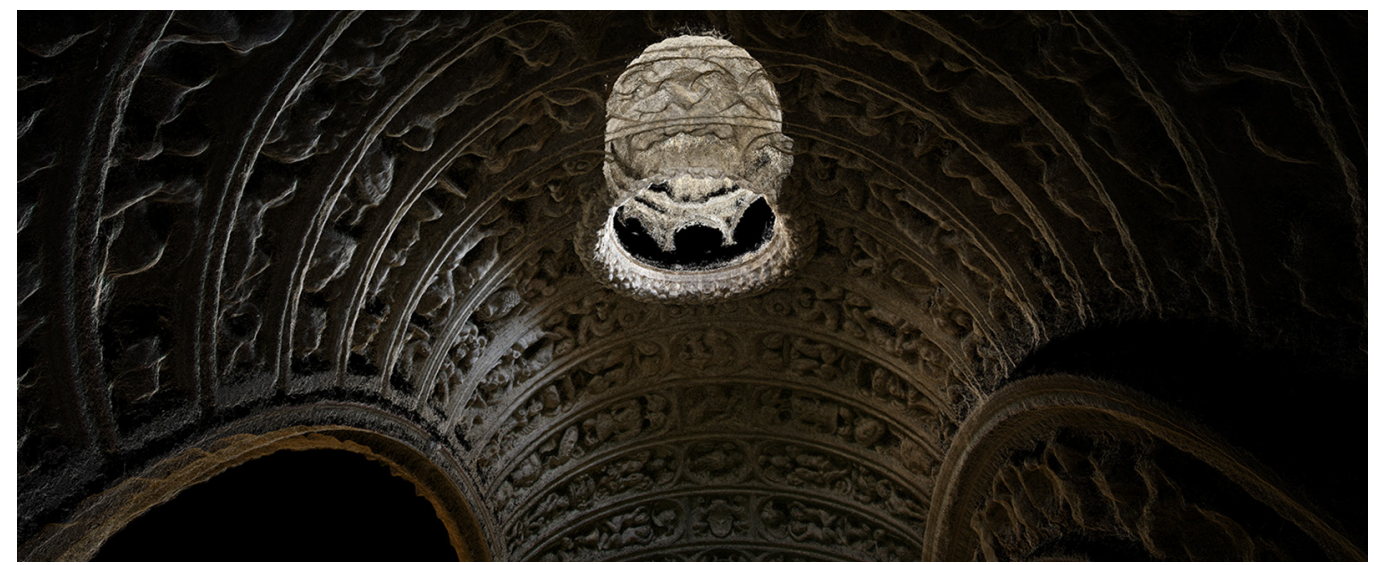


The Murcia Cathedral (Spain) is the outcome of an unwearying construction activity which started first from the bulding of Capilla de los Vélez in 149I and lasted until I570 [Gutiérrez-Cortines Corral 1987]. Among the main supporters of this project one can find the protonotary apostolic don Gil Rodríguez de Junterón ( I 480?-1552) a prelate who lived and worked in Rome for a period in the earlier 1500s. After the return to his homeland, Junterón decided to commission the construction of a funeral chapel named after him. Thus far it is considered one of the most impressive structures in the whole building complex in terms of formal complexity and decorative aspects. In general, this Murcia religious complex represents the prime model of the Spanish stereotomic school which considers Alonso de Vandelvira (I 544- 1 626) to be as one of the most important essayists. As it happens in those built in the mid-20s of sixteenth century in the same cathedral, this funeral chapel shows a style which recalls Italian Renaissance: in particular it refers to the architectonic production by Filippo Brunelleschi ( | 377- I 446), Bramante (I 444- I I I 4) and Michelangelo (I 475- I 564). This fact has not to surprise since many of these rooms have been created by the painter and architect Jacopo Torni (1476-1526) called Jacopo Fiorentino at the time [1]. In addition

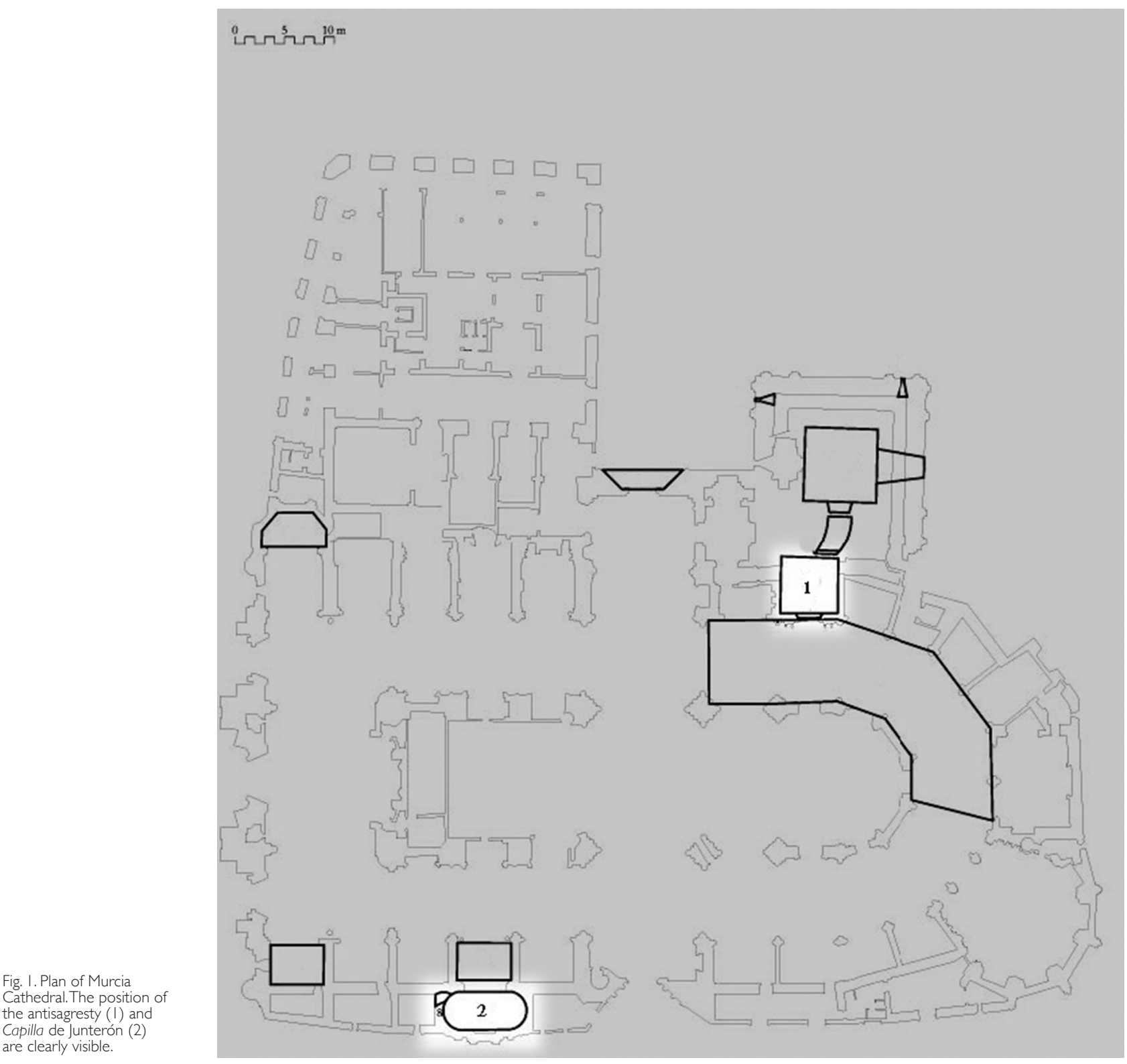


to this funeral chapel,Torni was also the author of the belling tower's first order, the sagresty, the antisagresty and the vaulted passage connecting the two environments. This text is going to describe some hypotheses on the potential geometric strategies to be used in order to divide the ashlars of Capilla de Junterón's vault and those in the antisagresty (fig. I).

The Capilla de Junterón (fig. 2) is characterised by a rectangular plan surrounded by two semicircumferences on the shorter sides. This building plan is defined as an ovalada or an imperfect oval by Vandelvira. At the time -in terms of composition considering such a mapping configuration- it was generally common to include a barrel vault covering the rectangular area and two quarters of sphere on the two borders of the remaining curvilinear parts.

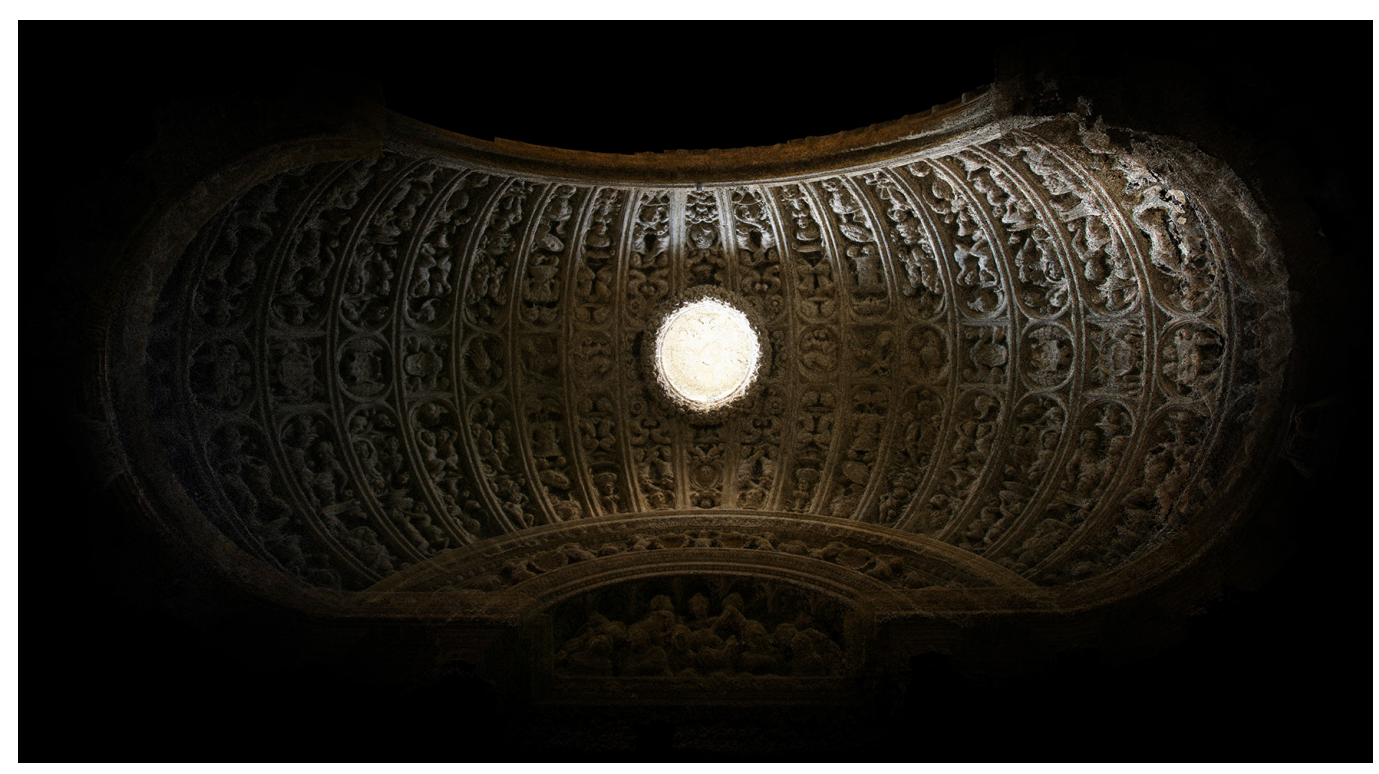

Torni's solution, instead, appears to be quite obsolete: as a matter of fact it deals with an annular vault comparable to a quarter of torus resulting from the 180 degrees rotation of one of the semi-equator around the transversal axis of the impost (fig. 3a). This environment is lighted by some small windows which are on the vertical surfaces, but also by a cilindric lantern put at the centre of the vault's upper part. As it was already known in the Roman epoch, it was more common to use a semi-torus covering the circular colonnade, but in that case the axis of the surface is oriented vertically like in the Mausoleum of Santa Costanza in Rome (approx. 340). In his treatise Vandelvira [Vandelvira I585c.; Barbé-Coquelin de Lisle 1977] proposes to divide the surface through the use of two series of coaxial cones: the first series is characterized by a common vertex and a horizontal axis which corresponds to the transversal one of the plan; the second series is characterized by an axis which follows the same direction, even if it has varied vertexes [Lopez 2005, pp. 123-136] [2]. The Spanish essayist agrees that the most useful method to obtain the stereotomic apparatus is the same used in capilla redonda en vuelta redonda or rather the hemispherical vault. Although both surfaces are considered to be the resulting rotation of the circumference around an axis, the solution -previously explained-causes a certain astonishment which has to be clarified. In the treatises of this period such problem is often repeated and refers specifically to the use of ruled surfaces, in order to make approximate the lower surface of every ashlar. In fact, since they are portions of spheres, are not developable and it's difficult to connect them to the so-called paneaux. So, the examined cones will have a common axis and a variable vertex depending on the inclination of the generatrices that, while approaching the surface's equator, tend to be parallel to the axis of revolution. It emerges the extreme case close to the equator where the cone has an improper vertex, so it reduces the lower surfaces as portions of a cilinder (fig. 3c). In such cases the use of ruled developable surfaces 
Fig. 3. Geometric reconstruction of the figure in Alonso de Vandelvira's treatise (a): project concerning the subdivision of the stereotomi apparatus into meridians and parallels (b) and the approximation of the ashlars' intradox faces into portions of cones (c) (digital model by A Bortot). became a common routine, a sort of geometric shortcut which was able to maintain an acceptable margin approximation as demonstrated by other authors [Rabasa-Díaz 2000, pp. |74-175]. The problem certainly caught the scholars' attention, even if it was necessary to await the first decades of I700s -in particular Jean-Baptiste de La Rue's work ( I 697- I 743) - in terms of more refined geometrical solutions practically based on a method which could be defined as "overturning" [Bortot, Lopez 2020, pp. 2 I-34]. The figures of Vandelvira's treatise which are combined with the description of the Junteron chapel's vault are two. Both show their own surface by means of a couple of orthogonal projections (more in detail: an upper and a frontal view). While the first figure focuses on the projection of the ashlars' grout lines in a sort of mutual coordination, the second one proposes a rib decorative apparatus which can be integrated to the whole structure (fig. 4). The observation of the vault during the survey and the following analysis of the Spanish essayist's projections allowed

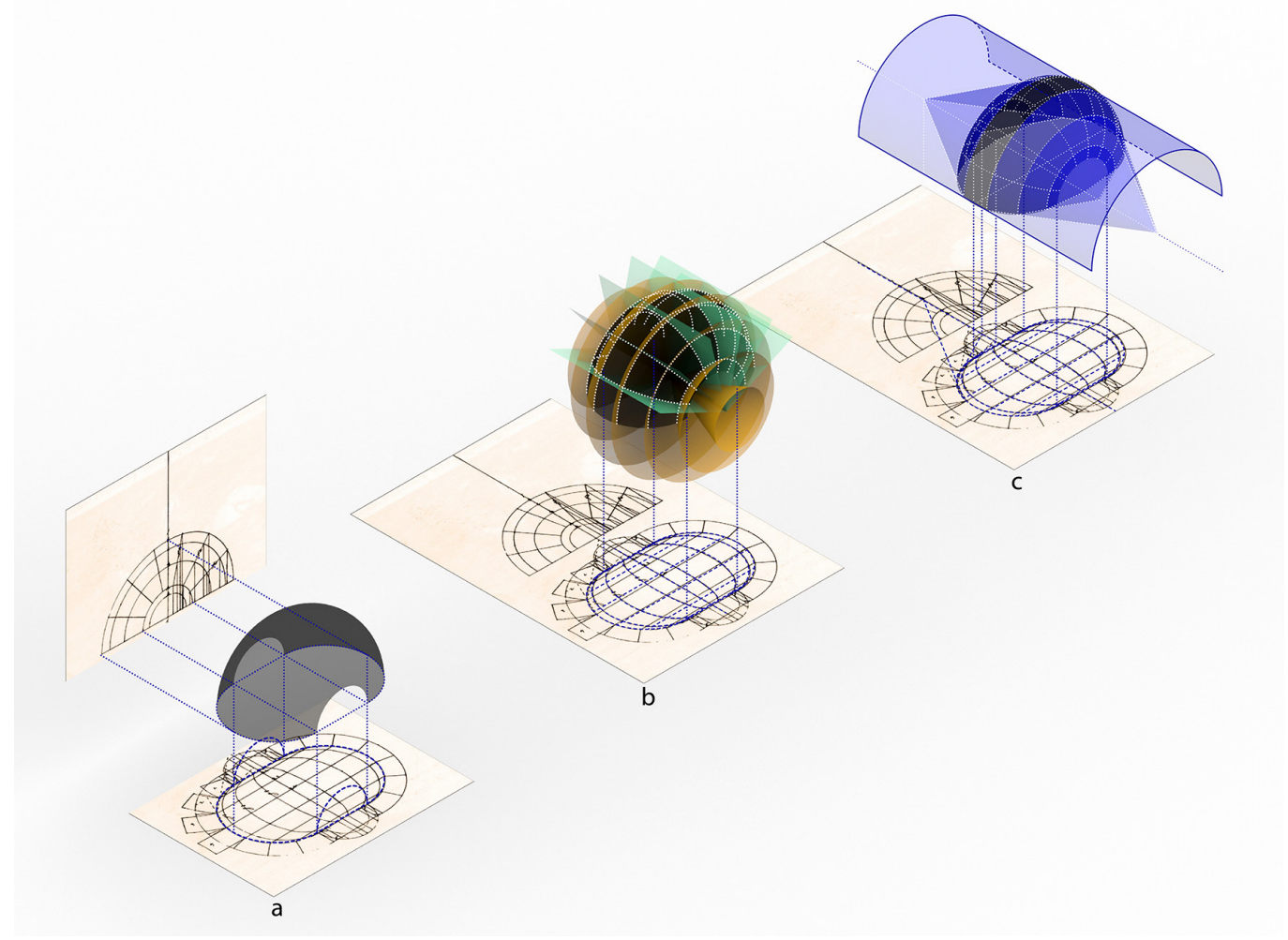

us to speculate on geometric elements: after they have intersected the portion of annular vault, they can allow to define meridians and parallels. While intersecting a series of cones (in this case with common vertex -corresponding to the centre of the ovoid- and with horizontal axis coinciding with the transversal one of the ovoid) with the portion of toroid, there is a generation of parallels which are comparable to the ones drawn by Vandelvira. Instead, through the intersection of a horizontal sheaf of planes, it is assured the production of hemi-circumferences in the space which, after being projected on the horixontal plane, show the meridians in the form of ellipse arches (fig. 3b). This latter is the closest solution to Vandelvira's drawing and, among other things -as we'll soon explain - it is the one that can be applied to the division of a hemispherical vault into ashlars. So, this solution is able to offer a clear intepretation of the Andalusian essayist's statement concerning the supposed stereotomic analogy between spherical and annular vaults. In addition to the originality of the structure, the described vault surprises for its hyper-decorativism: pagan images, often uncanny, seem to wriggle and arise from the single stony blocks. Moreover, they seem to allude more to a cathartic passage and to an ascesis towards eternity than a funeral dimen- 
Fig. 4.The Bóveda de Murcia from A. de Vandelvira's manuscript (on the left); the Bóveda de Murcia por cruceros from A de Vandelvira's manuscript (on the right) sion [Vilella 1998, p. 93]. The sculptural high reliefs show an inclination of the stereotomic technique in Spanish area which marks a meaningul difference if compared to the contemporary cases in French context. In fact, these ones often show a structural plainness without extra decorative elements.

The vault covering Murcia Cathedral's antisagresty (fig. 5), built in the early 1600s, is connected to the treatise by Alonso de Vandelvira (1544- |626), where it is described as capilla redonda en vuela capazo. The hemispherical vault is placed on four spherical pendentives which are leaning against four arches, respectively following the walls which surround the
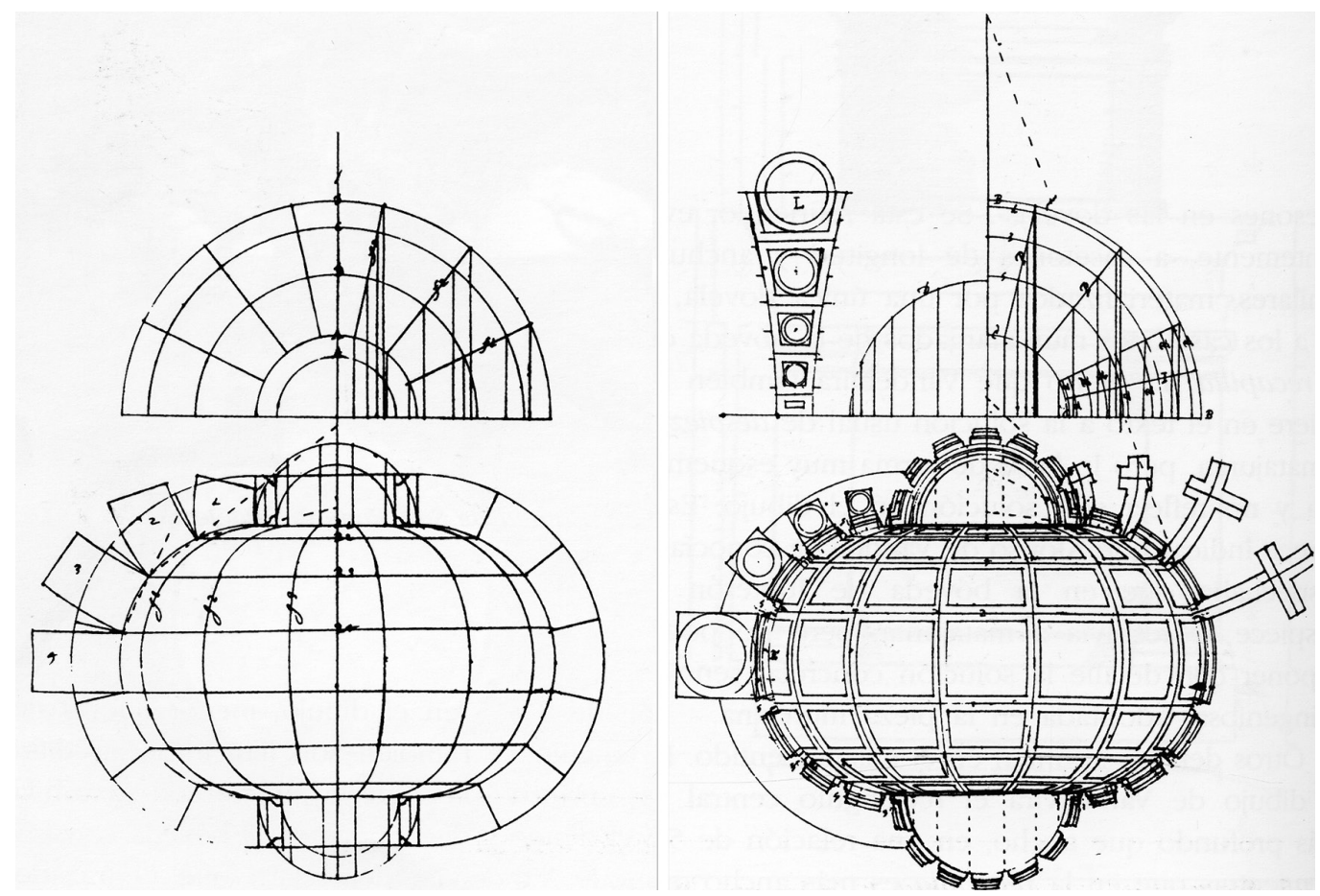

square room. Probably due to the collapse of the first order of the belling tower during the construction, this structure has been subjected to meaningful changes which are currently visible. Although in 2001 the restoration smoothed the dissimilarities among the ashlars of the vault and among those in the pendentive of the north-eastern part. The survey allowed to observe the extrados surface of the dome through a secondary passage which represented the entrance to the room above the antisagresty (fig. 6). On the extrados surface the ashlars appear to be rough-hewn in a more precise way, in order to follow the spherical shape of the extrados like in a three-dimensional offset operation. Moreover, one can find a binding agent which reinforces the connection of the joints, probably inserted during the restoration - we previously mentioned.

It's a quite rare case of subdivision of a spherical cap into ashlars based on a helicoidal path of the blocks. As already observed by Calvo José Lopez [Lopez 2005], an illustration of this problem arises in Vandelvira's manuscript (fig. 7a) and in Philibert de L'Orme's text [De l'Orme 1567], (I5 I4- I570) who defines it en forme d'une coquille de limaçon (fig. 7b). When comparing it with De l'Orme's figure, one can immediately notice a certain discrepancy, especially if Murcia vault is taken into consideration. In fact the height of the series is approximately the same: this fact brings to the thought that when projecting the drawing of the helix on the horizontal plane, a logarithmic spiral (the distance among them is bigger and bigger) and not an Archimedean one (the distance of the spirals is constant) arises. As a matter of fact, if we obtained a counterprojection of De l'Orme's logarithmic spiral from 
Fig. 5. Axonometric view of the textured mesh model of the antisagresty's vault (digita model by A. Bortot).

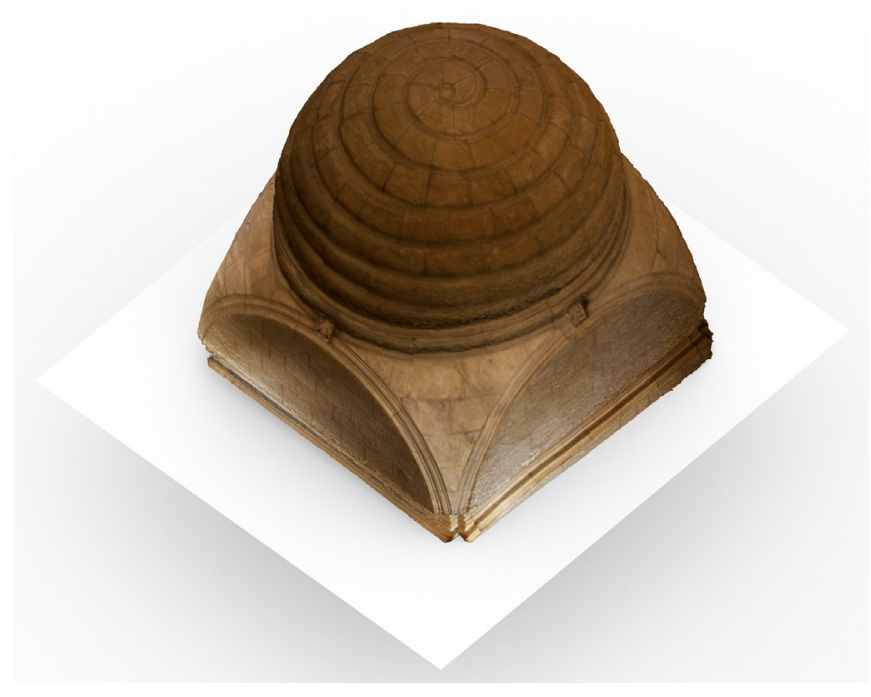

the impost towards the hemispherical surface, we would acquire a spherical helix with a variable height of spirals, and so for the series. The graphical incongruity described so far, appears in both manuscripts [Ruiz |560c.] by Hernán Ruiz el Joven (1514-1569) and by Jean Chereau (Chéreau 1570) - only to mention some of the authors who focused on this issue [3] The analysis on Alonso de Vandelvira's drawing carried out by José Calvo Lopez, illustrate, instead, how the figure represents the spiral of the planimetric projection starting from the spatial helix to be obtained. The procedure consists in determining first the height of every series of ashlars dividing the vertical section into equal parts. Then one has to divide the circumference of the plan into the same amount of blocks: from these points some straight lines are drawn towards the center of the vault, so the directions of the meri-

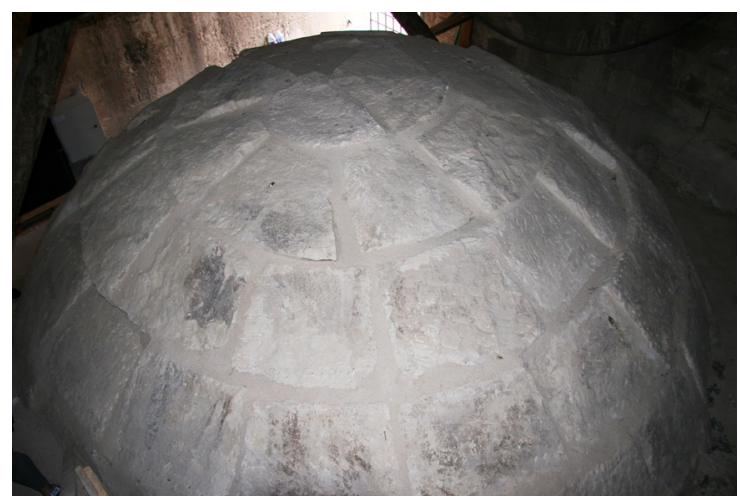

dians - projected on the horizontal plane- are acquired on the spherical surface.Then, while projecting the sectors in section, it will be possible to pinpoint the constant distance among the turns of the spiral (in their first projection) on the straights lines previously identified that is to say, those which define the portions of the meridians. At this point it will be possible to draw the first projection of the spiral and know both the center and the distance among the single turns in a coherent way in respect with the vertical section (fig. 8). A spatial helix will correspond to this kind of spiral which can refer to the bed joints of the various blocks which, as a consequence, will be different from each other.The drawings by De l'Orme and the other authors already quoted, except for Vandelvira, are definitely unrealisable. It's unlikely that a stonecutter had agreed in working on a stereotomic sequential structure 
Fig. 7.The Capilla redonda en vuelta capazo from Vandelvira's manuscript en forme d'une coqulle de limaçon from Le premier tome de l'Architecture by Philibert de L'Orme (on the right).
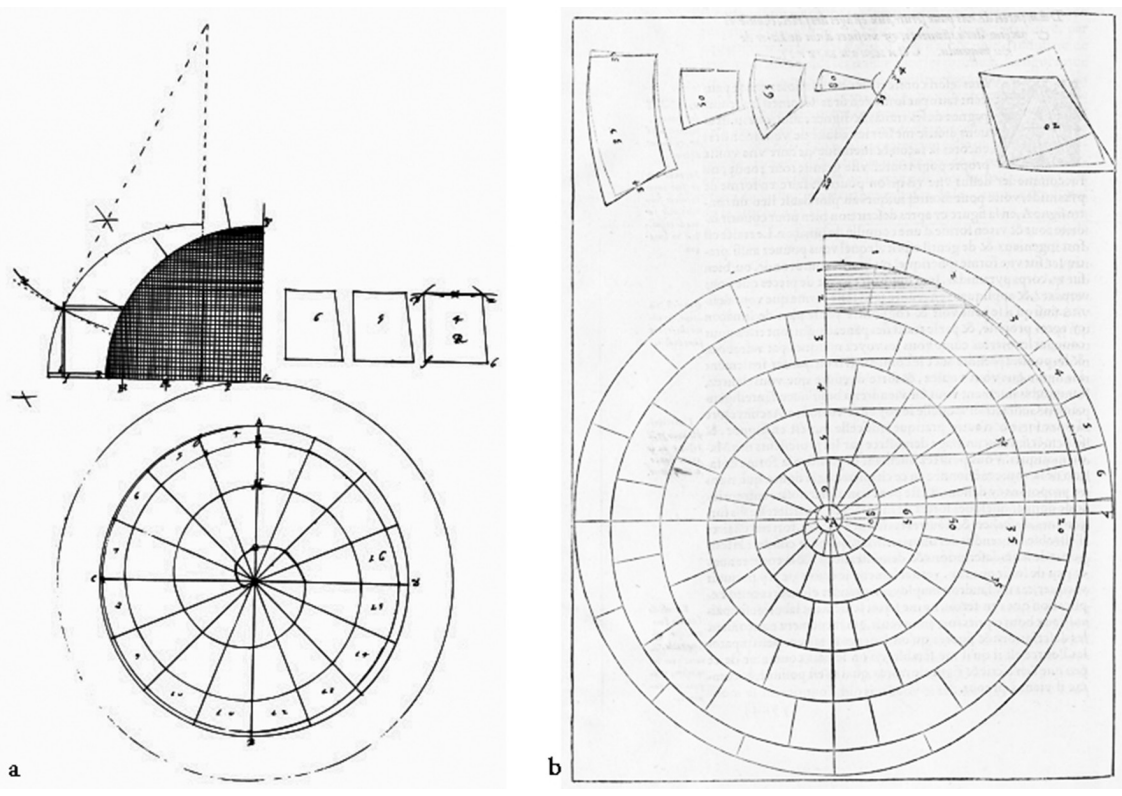

with different heights. Maybe it could have been happened only for a precise static reason which, anyway, it is difficult identify in this specific case.

The digital reconstruction of Murcia Cathedral's vault is based on the geometrical analysis of this structure and the use of a textured mesh model of the intradox surface obtained from techniques connected to stereo-photogrammetry [4] (fig. 5). Considering the deformations of the vault due to the collapse of the belling tower during the construction, a first survey focused on the identification of the spatial curve which characterises the bed joints. At the beginning we speculated on a loxodrome -well-known in the field of nautical science to chart the courses- able to join any two points on Earth's surface intersecting all the meridians with the same angle (instead, the complementary curve -called 'orthodromic distance'- joins two points in their shorter arc). Redrawing this element directly on the digital clone, allowed to show that the curve looks like a spherical helix, despite with a certain approximation. So, the preliminary analyses allowed the reconstruction of a solid and rectified digital model of the antisagresty's vault and of the related subdivision into ashlars. The 'parallels' (as we simply define the joints lying on the spherical helix) have been obtai-
Fig. 8. Reconstruction of the method to set the constant height of the series in the antisagresty's vault (graphic elaboration J. C. López).

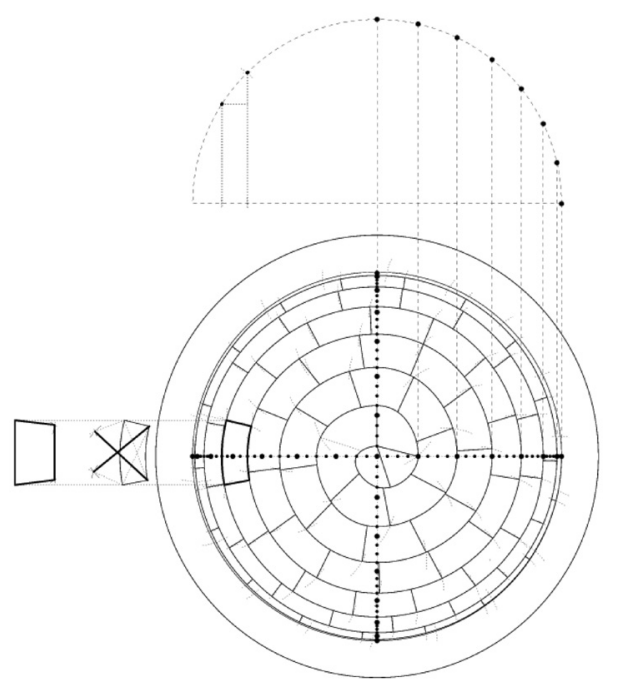


ned due to the intersection of the half sphere with a cone whose vertex has been placed at the centre of the square identified by the lower vertexes of the spherical pendentives and whose directrix is an Archimedean spiral with the same number of turns of those really existing (fig. 9). Instead, the 'meridians' have been obtained from the division of the cone's directrix spiral into the same number of existing segments, so drawing some straight lines which can connect every segment's endpoints to the centre of the curve. Then some portions of the straight lines (those included from a turn and another) have been projected on the half sphere (fig. I0). Finally an offset operation of the intradox surface has been carried out in order to obtain the extrados surface, moving from a surface model to a solid divided into ashlars (fig. I I) where every block has portions of cone as head ashlars and portions of planes as joint faces. The resulting digital model has partly rectified the structure's effective state of conservation except for the deformations due to the collapse of the tower. Instead, this model has followed the amount and shape of every single ashlar. For this reason, it is not surprising, in some cases, the lineup among the vertical joints of the consequential series that - although less efficient from the structural point of view - are placed in the antigresty's vault in this way.

This case study highlights the great influence of Spanish stereotomic practise in French context: Jean-Marie Pérouse de Montclos states that "the simple comparison of sixteenth-century stereotomic apparatuses recognises the eminent role of Spain as catalyst" [Pérouse de Montclos 1982]. Yet, the same author affirms that the case of capilla redonda en vuela capazo defined by De l'Orme as en forme d'une coquille de limaçon, is simply a sort of caprice, a virtuosistic subdivision of a hemispherical vault into ashlars: too complex to become a repeatable model. In fact there are a few analogous examples, although in Spanish area sometimes one can observe similar joints covering helicoidal staircases like the one in the tower of Palacio de los Guzmanes in León (second half of 1600s), or the one in Plasencia Cathedral or the other of Monastery of Santa Catalina in Talavera de la Reina.

Finally, in Vandelvira's literary work -whose broad spreading as a manuscript is already known- it is clearly perceivable a certain inclination towards the practical solution of every single case more than a focus on the research of a general method. This latter will involve, instead, all the French authors of the following century. According to us the drawing of Murcia antisagresty's vaut (with some geometrical licences) shows a certain coherence due to the construction practice more than the pure speculation. Since it comes from an

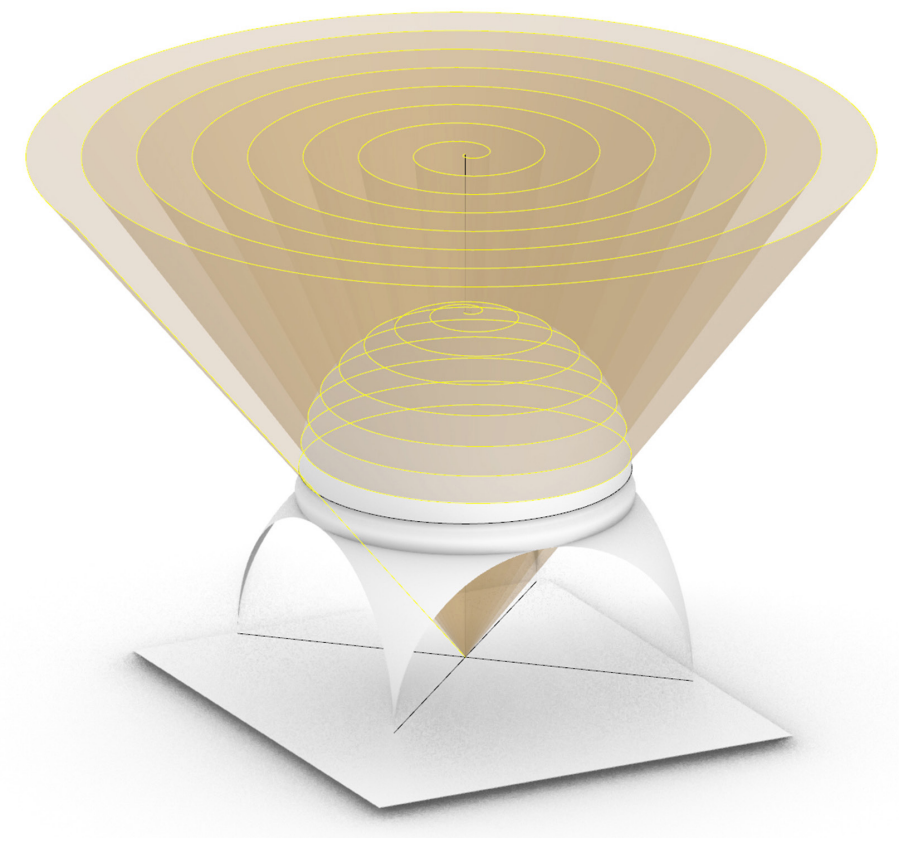


Fig. I0. Reconstruction of the subdivision of the vault into vertical joints

(digital model by
A. Bortot).
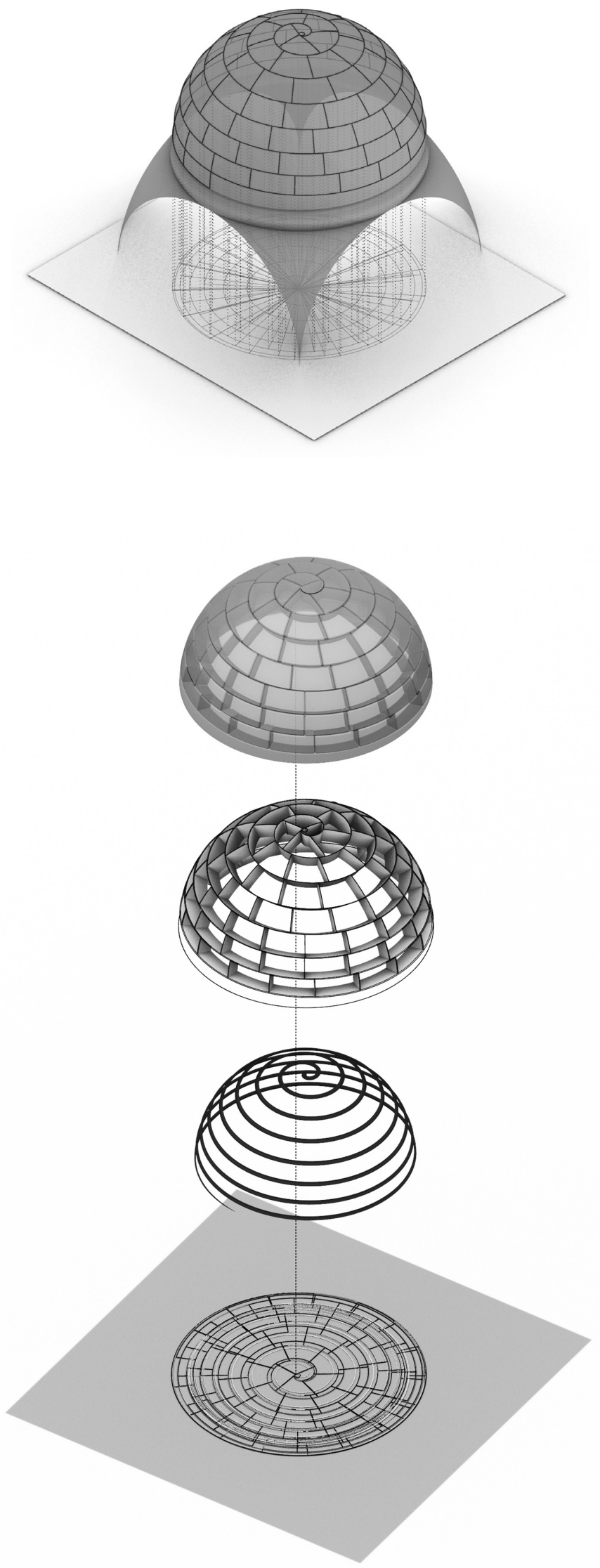
imaginative-projective habit which had developed in an epoch where project design had to concentrate on the solutions and not on the representation of its rigid execution. So digital stereotomy - used in this case to analyse the two case studies- cannot elude the bases of a coherent and detailed method which is to be considered the reasonable outcome of a tradition connected to this construction technique.

\section{Notes}

[I] On the biographic details referring to this author, there are only a few information. The main source is still Vasari's work: G. Vasari Giorgio (I 568). Vite de' più eccellenti pittori, scultori, e architettori. Firenze: appresso i Giunti.

[2] E. Trevisan, Intreccio strutturale e vertigine dello sguardo: tettonica, decorazione e attualità della stereotomia nella Cattedrale di Murcia, IUAV School of Doctorate Studies in Venice, supervisor Prof. A. De Rosa, a.y. 20 I 4-20 I5, unpublished Phd. thesis, pp. $125-143$.

[3] Similar drawings also appear in other manuscripts and treatises following the vault's construction in Murcia. For instance, one can refer to: Tosca Vicente (1794). Tratado de arquitectura civil, montea y cantería y reloxes. Valencia: Hermanos Orga; J. de Partor y Castro ( 1708). Cuaderno de arquitectura, Biblioteca Nacional, Madrid.

[4]The survey has been carried out through the use of a camera Nikon D800e equipped with $24 \mathrm{~mm}$ FI.4 aspheric lens. After setting ISO value to 200, we have taken 88 photographs in Jonteron's Capilla and 33 in the antisagresty's vault. The images have been processed with the Agisoft Metashape software.

\section{References}

Barbé-Coquelin de Lisle Geneviève (a cura di). (1977). Tratado de Arquitectura de Alonso de Vandelvira. Albacenete: Confederacion Espanola de Cajas de Ahorros.

Bortot Alessio, Calvo López José (2020). De la Rue's Traité de la coupe des pierres: a crucial step in the articulation of material stonecutting and abstract stereotomy. In Calvo López José, Bortot Alessio, Piccinin Giulia. Geometria e costruzione. Steretomia e configurazione in architettura. Roma: Aracne.

Calvo López José et al. (2005). Cantería renacentista en la catedral de Murcia. Murcia: Colegio de Arquitectos de Murcia.

Chéreau Jean (I570c.). Livre d'Architecture. s.e.

De L'Orme Philibert ( I567). Le premier tome de l'Architecture. Parigi: Morel.

Gutiérrez-Cortines Corral Cristina (1987). Renacimiento y arquitectura religiosa en la antigua Diócesis de Cartagena, Reyno de Murcia, Gobernación de Orihuela y Sierra del Segura. Murcia: Colegio de Aparejadores y Arquitectos Técnicos.

Pérouse de Montclos Jean-Marie ( 1982). L'architecture à la Française, XVle, XVIle, XVIlle siècles. Parigi: Picard.

Rabasa-Díaz Enrique (2000). Forma y construccion en piedra: De la canteria medieval a la estereotomia del siglo 19. Madrid: Ediciones Akal.

Ruiz el Joven Hernán (I560c.). Libro de Arquitectura. s.e.

Sakarovitch Joel (1998). Épures d'architecture: de la coupe des pierres à la géométrie descriptive, XVI-XIX siècles. Basilea: Birkhäuser.

Vandelvira Alonso ( 585 c.). Libro de trazas de cortes de piedras (manoscritto della Biblioteca de la Escuela de Arquitectura de la Universidad Politécnica de Madrid).

Vilella Marzia (1999). Jacopo Torni detto I'Indaco (I476-I526) e la cappella funebre "a La Antigua" di Don Gil Rodríguez de Junterón nella cattedrale di Murcia. In Annali di architettura. Rivista del centro internazionale di Studi di Architettura Andrea Palladio, I0-I I, pp. 82-102.

\section{Author}

Alessio Bortot, Università luav di Venezia, alessio.bortot@iuav.it

To cite this chapter: Bortot Alessio (2020). Dai tracciati alle strutture stereotomiche: analisi di alcuni sistemi voltati della Cattedrale di Murcia (Spagna)/From trait to stereotomic structure: analysis of some vaulted systems in the Murcia Cathedral (Spain). In Arena A., Arena M., Brandoli-
no R.G., Colistra D., Ginex G., Mediati D., Nucifora S., Raffa P. (a cura di). Connettere. Un disegno per annodare e tessere. Atti del $42^{\circ}$ Convegno no R.G., Colistra D., Ginex G., Mediati D., Nucifora S., Raffa P. (a cura di). Connettere. Un disegno per annodare e tessere. Atti del $42^{\circ}$ Convegno
Internazionale dei Docenti delle Discipline della Rappresentazione/Connecting. Drawing for weaving relationships. Proceedings of the 42 th International 